\title{
Extending the Storage-life of Mixed Fruits and Veggies Using a Cold Room (Ecofrost)
}

\author{
Parag Babaji Jadhav* \\ Agricultural Research Expert, Ecofrost Technologies Pvt. Ltd., Survey No 134/1, 134/2,130/3, \\ Jeevan Nagar, Tathawade, Pune, Maharashtra-411033, India \\ *Corresponding author
}

\section{A B S T R A C T}

Keywords

Mixed, Fruit, Vegetables, Ecofrost, Cold, Storage, shelf, etc.

Article Info

Accepted:

04 October 2018

Available Online:

10 November 2018
The longest storage life was recorded in Sweet Orange cv. "Mosambi", Mandarin cv. "Kinnow", Acid Lime, Pineapple cv. "Queen", Beetroot, Watermelon, Capsicum cv. "Bombay Green", Cabbage, Ivy Gourd, Bitter Gourd (Green) and Hot chilli, and the shortest in Broccoli, Lettuce and Ridge Gourd inside cold room. Storage at Ecofrost at $10^{\circ} \mathrm{C}$ and $93 \%$ relative humidity can extend life and improve post-harvest quality retention for fruit and veggies, but its effects vary depending on the commodity.

\section{Introduction}

India's diverse climate ensures availability of a variety of fresh fruits and vegetables $(\mathrm{F} \& \mathrm{~V})$. It ranks second in the production of fruit and vegetables after China. As per the National Horticulture Database published by the National Horticulture Board (http://apeda.gov. in/apedawebsite/index.html), This vast production base offers India tremendous opportunities for export. Production of horticulture crops like vegetables and fruits is likely to touch a record 305.4 million tonnes (MT) in 2017-18, about $1.6 \%$ higher than the previous year and $8 \%$ higher than the previous five years' average. The final estimates for 2016-17 released alongside showed that production of these perishable crops was
300.6 MT, a year-on-year rise of over $5 \%$. Within horticulture, production of vegetables is estimated at $181 \mathrm{MT}$ in $2017-18$, about $1 \%$ higher than the year before, while that of fruits is estimated at $95 \mathrm{MT}, 2 \%$ higher than the previous year's (https://www.livemint.com/ Politics/V7EcEZlz9jT3bjLsyoiSpK/Horticultu re-crop-output-seen-at-record-3054-mt-in201718.html).

Eating a diet rich in fruits and vegetables can help lower your risk of many health conditions, including high blood pressure, heart disease, stroke, and certain kinds of cancers. But if they're not handled properly, fruits and veggies can also become a source of food-borne pathogens. For example, they can become contaminated with listeria, 
salmonella, or other bacteria. Their taste, texture, and appearance can also suffer if they're not stored properly.

Fruits and vegetables are an important part of a well-balanced diet. The United States Department of Agriculture advises diners to fill half their plate with fruits and veggies at every meal. Adult women should eat about 1 $1 / 2$ to 2 cups of fruit and 2 to $21 / 2$ cups of vegetables every day. Adult men should eat about 2 cups of fruit and $2 \frac{1}{2}$ to 3 cups of vegetables per day (https://www.healthline. com/health/food-safety-fruits-vegetables).

When different fruit and vegetables are stored together, they may be tainted by odours given off by one another. Optimum storage temperatures and relative humidity required for different items also vary, as do their ethylene sensitivities. Some fruits and vegetables are sensitive to low temperatures and suffer a 'chilling injury' if stored below critical temperature. Ethylene (natural gas) has a harmful effect on some vegetables, e.g. yellowing of broccoli, so ethylene-producing and ethylene-sensitive commodities must not be stored together. If mixed storage of fruits and vegetables cannot be avoided, it should be done only for a short period such as a few days to a week and care must be taken to store only compatible products together. Lettuce, carrots, broccoli and some flowers deteriorate rapidly if stored with pears, apples, bananas, avocados, peaches, plums and other produce that give off ethylene. Product such as honeydew melons etc. produce ethylene, and those that are sensitive to ethylene such as French beans and cucumbers, should not be stored with them.

This study was carried out to determine the storage life in days when storing fruits and vegetables together inside cold room of Ecofrost $\left(10^{\circ} \mathrm{C}\right.$ and $\left.93 \% \mathrm{RH}\right)$.

\section{Materials and Methods}

A laboratory study was carried out at Ecofrost Technologies Pvt. Ltd., India during August, 2016 to determine the effectiveness of combined storage of fruit and vegetables. Uniformly healthy fruit and vegetables harvested roughly 1 to 3 days earlier were purchased from Pimpri Chinchwad Market.

Papaya, Custard Apple, Sweet Oranges, Mosambi, Acid Lime, Pineapple-Cv. 'Queen', Capsicum, Watermelons, Sweet Baby Corn, Beetroot, Okra, Tomatoes, Ivy Gourd, Cabbage, Bitter Gourd, Drumsticks, Green Beans, Muskmelons, Cucumbers, Chillies, Indian Beans, Broccoli, Ridge Gourd, Lettuce and Radishes were harvested at optimum stage of maturity and transported in ambient conditions by car two and half hours to the Agricultural Research Laboratory at Ecofrost Technologies Pvt. Ltd., Pune, and immediately prepared for storage. $5 \mathrm{~kg}$ of each commodity were stored 11 days in a cold unit of Ecofrost at $10^{\circ} \mathrm{C}$ and $93 \%$ Relative humidity to measure mondi life of commodities.

Shelf life of the produce was determined by observing and judging different parameters with respect to storage days at ordinary room conditions. Similarly, cold storage life (days) was determined by observing and judging the same quality parameters with respect to storage days (Jadhav and Gurav, 2018).

\section{Results and Discussion}

\section{Storage-life}

Storage-life of mixed fruits and vegetables (Table 1, Figure A and Photo 1) inside cold room was studied. The experimental results showed highest storage-life in Sweet Orange cv. "Mosambi", Lime, Pineapple cv. "Queen", Beetroot, Watermelons, Capsicum, Cabbages, 
Ivy Gourd, Bitter Gourd and Hot chillies, and the lowest in Broccoli, Lettuce and Ridge Gourds.

In Broccoli and Ridge Gourd, fungus developed on surface of the curd of flowers and fruit within 2.5 and 3 days of storage inside cold room, respectively. Chilling symptoms were observed in tomatoes after 4 days of storage inside cold room, when harvested at the pink stage. Watery Sunken spots were also seen on the tomato's surface. Shrivelling symptoms appeared in drumsticks after 11 days of storage. In custard apples, slight cracks were seen at the end of 8 days of storage. Bean loosening occurred after 11 days of storage. Cold storage helped in suppressing enzymatic degradation and respiratory activity (softening), slowing or inhibiting water loss (wilting), slowing or inhibiting growth of decay producing microorganisms (mold and bacteria), reducing production of ethylene (a ripening agent) and/or minimizing the product's reaction to ethylene. In addition to protecting quality, post-harvest cooling provided marketing flexibility by making it possible to market the product at the optimum time (Jadhav and Gurav).

Table.1 Storage-life (days) of mixed fruits and vegetables at $10^{\circ} \mathrm{C}$ and $93 \% \mathrm{RH}$ under cold storage unit of Ecofrost

\begin{tabular}{|c|c|c|c|}
\hline Sr. No. & Commodity Name & $\begin{array}{l}\text { Storage life (days) } \\
\left(10^{\circ} \mathrm{C} \text { and } 93 \% \mathbf{R H}\right)\end{array}$ & $\begin{array}{l}\text { Shelf-Life (days) at } \\
\text { Room temperature }\end{array}$ \\
\hline 1. & Capsicum cv. "Bombay Green" & $11^{* *}$ & 3 \\
\hline 2. & Watermelon & $11^{* *}$ & 5 \\
\hline 3. & Beetroot, Red type & $11^{* *}$ & 4 \\
\hline 4. & Sweet Orange cv. "Mosambi" & $11^{\text {***}}$ & 4 \\
\hline 5. & Okra & $10^{*}$ & 3 \\
\hline 6. & Papaya cv. "Taiwan 786" & 9 & 2.5 \\
\hline 7. & Tomato, Pink stage 4 & 4 & 2.5 \\
\hline 8. & Ivy Gourd & $11^{* *}$ & 2.5 \\
\hline 9. & Cabbage & $11^{* *}$ & 2.5 \\
\hline 10. & Bitter Gourd, Green Type & $11^{*}$ & 2.5 \\
\hline 11. & Drumstick & $9^{*}$ & 2.5 \\
\hline 12. & Custard apple & 8 & 2.5 \\
\hline 13. & Green Bean & 9 & 2.5 \\
\hline 14. & Mandarin cv. "Kinnow" & $11^{* *}$ & 5 \\
\hline 15. & Acid Lime & $11^{* *}$ & 3.5 \\
\hline 16. & Pineapple cv. "Queen" & $11^{* *}$ & 3 \\
\hline 17. & Muskmelon & $11^{*}$ & 3 \\
\hline 18. & Cucumber, White colour & $10^{*}$ & 2.5 \\
\hline 19. & Chilli (Hot) & $11^{* *}$ & 3.5 \\
\hline 20. & Indian Bean & 9 & 2.5 \\
\hline 21. & Broccoli & 2.5 & 1 \\
\hline 22. & Ridge Gourd & 3 & 2 \\
\hline 23. & Radish & $11^{* *}$ & 2.5 \\
\hline 24. & Lettuce & 2.5 & 1.5 \\
\hline
\end{tabular}




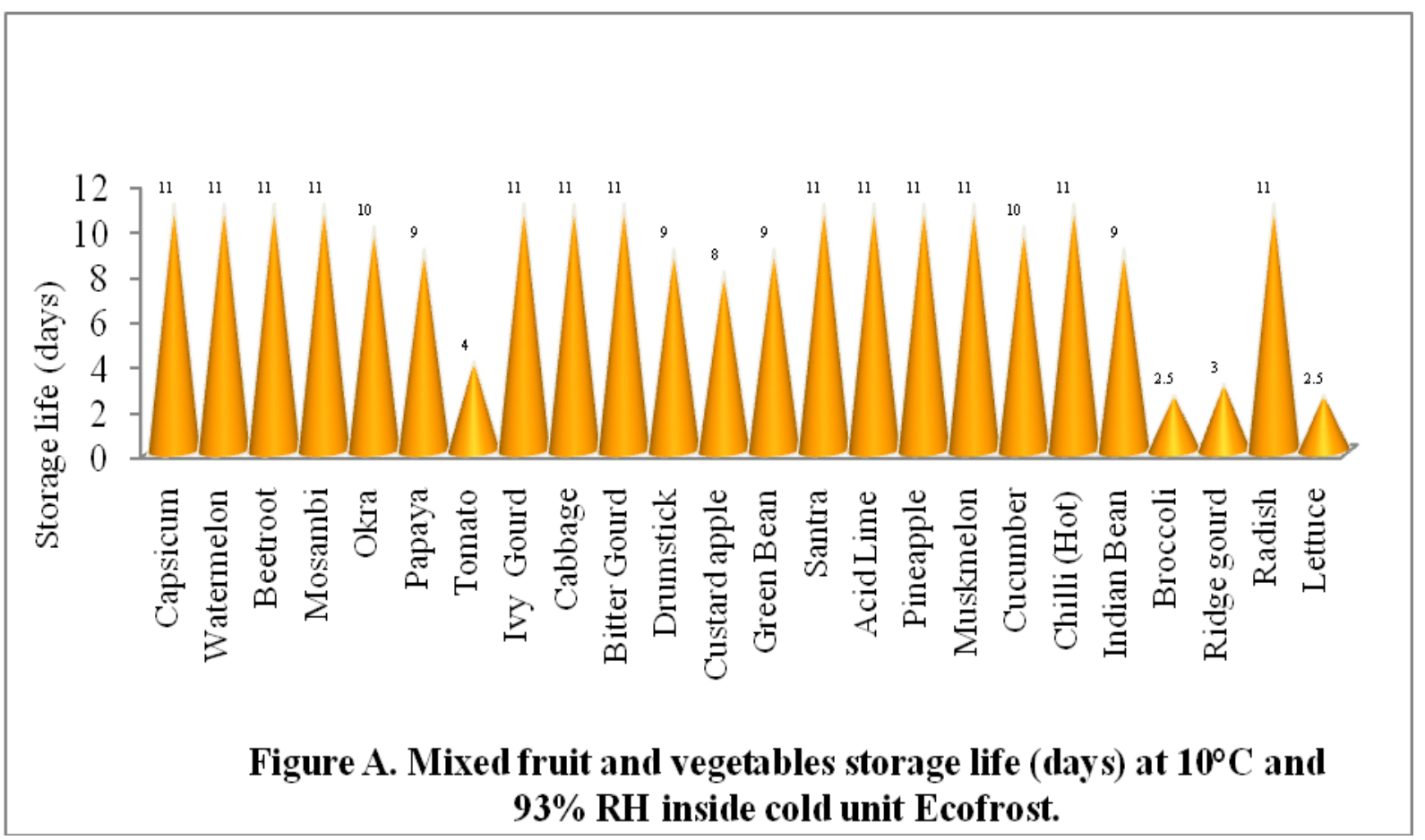

Photo.1 Mixed fruits and vegetables kept at cold storage $\left(10^{\circ} \mathrm{C}\right.$ and $\left.93 \%\right)$

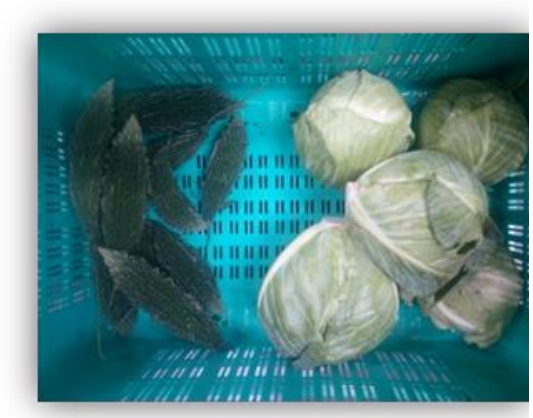

Bitter Gourd and Cabbage

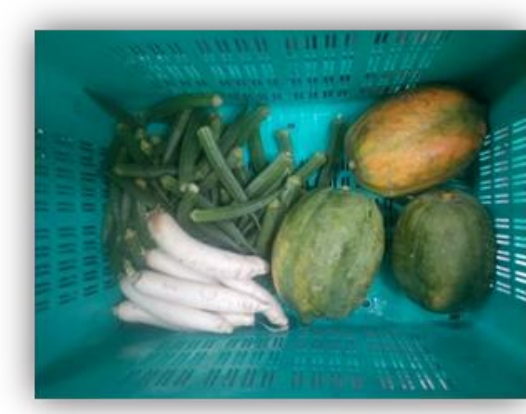

Lady Finger (Okra), Radish and Papaya cv. "Taiwan 786"

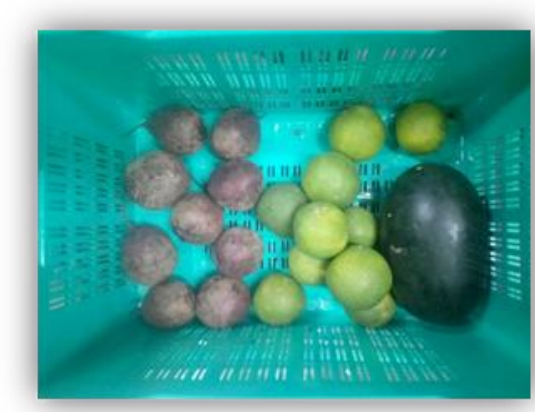

Beet Root, Sweet Orange cv. "Mosambi" and Watermelon

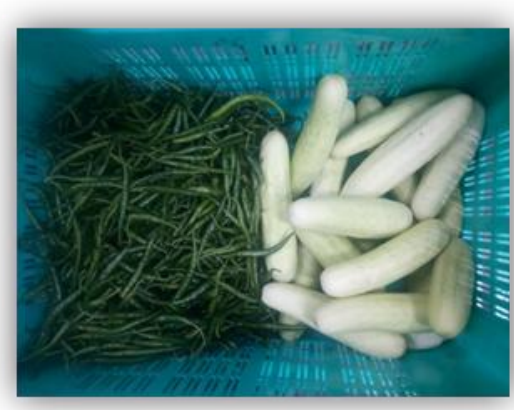

Hot Chilli and Cucumber

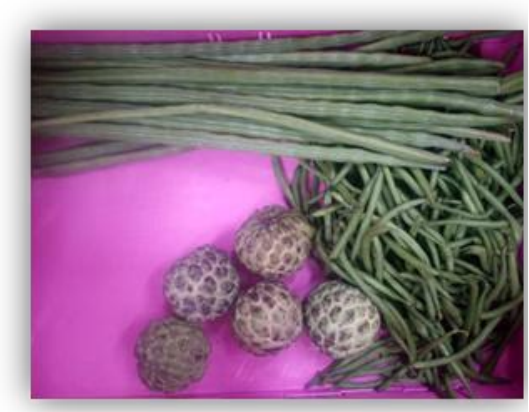

Drumstic, Custard Apple and Green bean

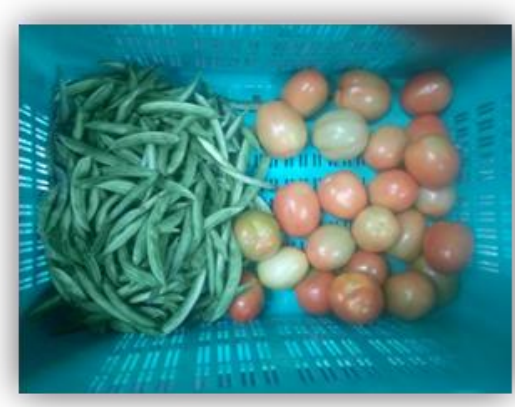

Indian Bean and Tomato (Pink stage) 

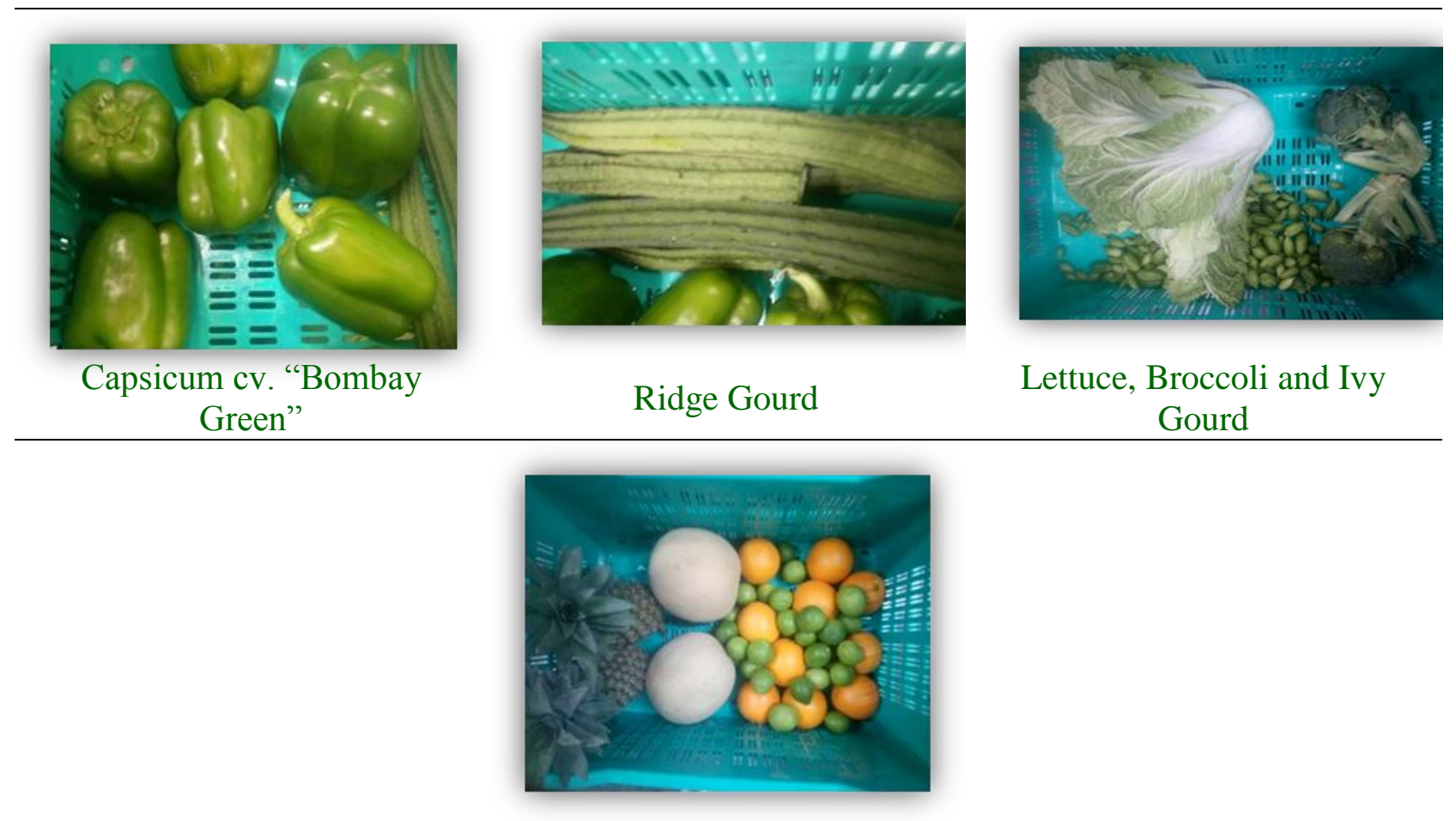

Pineapple cv. "Queen", Muskmelon, Acid Lime and Mandarin cv. "Kinnow"

In conclusion, low temperature storage can extend life and improve post-harvest quality retention for fruits and vegetables, but its effects vary depending on the commodity. In this study, some commodities had a shorter storagelife (e.g. Broccoli and Ridge Gourd). Similarly, some commodities (Mandarin cv. "Kinnow", Sweet Orange cv. "Mosambi", Watermelon, Ivy Gourd, Pineapple cv. "Queen", Radish, Hot chilli, Capsicum cv. "Bombay Green", Beetroot, Acid Lime, etc) exhibited longer storage life (days) under the same conditions.

\section{Acknowledgement(s)}

The author(s) are grateful to the Directors of Ecofrost Technologies Pvt. Ltd., Survey No 134/1, 134/2,130/3, Jeevan Nagar, Tathawade, Pune, Maharashtra - 411033 for providing facilities for conducting research on storage of different fruit and vegetables at $10^{\circ} \mathrm{C}$ and $93 \%$ RH inside cold unit of Ecofrost.

\section{References}

http://apeda.gov.in/apedawebsite/index.html https://www.healthline.com/health/food-safetyfruits-vegetables

https://www.livemint.com/Politics/V7EcEZlz9j T3bjLsyoiSpK/Horticulture-crop-outputseen-at-record-3054-mt-in-201718.html

Jadhav PB, and Gurav NP. (2018). Extending the Storage and post-storage shelf-life of strawberry fruit cv. "Sweet Charlie" using cold storage. Int. J. Res. Rev., 9(3): 532542.

Jadhav PB, and Gurav NP. Extension of storage and post-storage shelf-life of fig fruit. Int. J. Res. Rev., 5(3):25-34.

\section{How to cite this article:}

Parag Babaji Jadhav. 2018. Extending the Storage-life of Mixed Fruits and Veggies Using a Cold Room (Ecofrost). Int.J.Curr.Microbiol.App.Sci. 7(11): 25-29. doi: https://doi.org/10.20546/ijcmas.2018.711.004 